\title{
1833 Tarihli Nüfus Defterine Göre Üsküp Kazası'nın Demografik Yapısı
}

\author{
The Demographic Structure of Skopje from the 1833 Register
}

\section{Hatice AKIN ZORBA*}

Öz: Bugün Makedonya Cumhuriyeti'nin başkenti olan Üsküp, Vardar Nehri'nin iki yakasına kurulmuş bir şehirdir. 1392'de Osmanlı yönetimine dâhil edildiği andan itibaren Osmanlı yönetiminin en önemli uç bölgelerinden biri haline gelmiştir. 1463'ten sonra kaza statüsü verilen Üsküp'e Saruhan bölgesinden Türkmenlerin yerleştirilmesiyle nüfusun yoğunluğu ve niteliği değişime uğramaya başlamıştır. Müslümanlar genellikle Üsküp şehrinde yaşamayı tercih ederken, Hıristiyanlar yoğunlukla kırsal alanda yaşamlarını sürdürmüşlerdir. Ancak bu durum zamanla değişim göstermiştir. Çoğu kırsal alanda yaşayan gayrimüslimlerin fetihten 1832'ye kadar geçen süre zarfında yavaş yavaş şehir merkezine yerleşmeye başladıkları tahrir defterleri üzerinde çalışmalar yapmış olan tarihçiler tarafından tespit edilmiştir. Yüzyıllar içinde 70'e kadar çıkış Üsküp şehrindeki mahalle sayısı 1832'de 47'ye kadar düşmüştür. Üsküp'e bağlı köy sayıları da değişiklik arz etmiştir. Gayrimüslimlerden alınan cizye vergisi ile askeri ihtiyaçlara yönelik Müslüman erkek sayısının tespit edilmesi amacına yönelik yapılan 1831 sayımı her ne kadar hatasız kabul edilemese de Osmanlı topraklarının sayım yapılan bölgelerindeki nüfusu hakkında fikir vermesi açısından büyük öneme haizdir. Çalışmanın amacı 1833 tarihli nüfus defterine göre Üsküp Kazası'nın nüfus yapısını ortaya koymaktır. Çalışmanın temel kaynağını oluşturan BOA NFS.d. 5624 numaralı Nüfus Defteri Üsküp Kazası'nın mufassal defterlerinin icmallerinden oluşmaktadır. Defterdeki veriler Üsküp merkezi ve köylerindeki nüfus yoğunluğu ve nüfusun yerleşim yerlerine göre dağılımı hakkında bilgi verirken aynı zamanda nüfusun dinsel açıdan dağılımını da ortaya koymaktadır. Ayrıca gayrimüslimlerin ödemekle yükümlü oldukları cizye miktarına dair veriler Üsküp’te yaşayan gayrimüslim reayanın ekonomik durumu hakkında da bilgi vermektedir.

Anahtar sözcükler: Osmanlı Devleti, Üsküp, Nüfus, Müslüman, Gayrimüslim, Cizye

\begin{abstract}
Skopje, the capital city of The Republic of Macedonia, is located on both sides of the Vardar. The city became one of the three important frontier regions in 1392 when it was conquered by the Ottoman State and, after 1463 the city gained county status. The size and quality of the population of Skopje began to change with the settlement of the Turkmen coming from the Saruhan region. The Muslim population occasionally preferred to live in the downtown area, while the Christian population preferred to live in rural areas, which, however, changed over the centuries. It is shown by scholars who have the studied tax records that the Christian population living in rural areas around the city since the conquest gradually, over the centuries moved towards the centre. The number of neighborhoods in the city increased to 70 while in 1832 this number was reduced to 47, and accordingly the number of villages changed. Although the 1831 census, taken in order to determine jizya tax levied on the Non-Muslims subjects, and for military service and the number of the male population, is not acknowledged as flawless, it provides some valuable information about the regions included in the census. The aim of this study is to show the population structure of Skopje according to the register of 1833. The register (BOA NFS.d. 5624), the main source employed in this study, contains various detailed records. The information recorded shows the size of the population in the city center and the villages of Skopje and the distribution of population in the settlements and in religious groups. In addition, the register also provides valuable information about jizya tax and the economic conditions of the non-Muslim citizens.
\end{abstract}

Keywords: The Ottoman Empire, Skopje, Population, Muslim, Non-Muslim, Jizya

* Dr. Öğr. Üyesi, Akdeniz Üniversitesi, Edebiyat Fakültesi, Tarih Bölümü, Antalya. hakin@akdeniz.edu.tr 


\section{Giriş}

Osmanl1lar tarafindan fethedildiği 1392'den Belgrad'ın fethedildiği 1521 tarihine değin Üsküp Balkanlardaki "en önemli" Osmanlı şehri olma özelliğine sahip olmuştur. Fethinden sonra Osmanlı yönetimi tarafından şehrin kültürel ve iktisadi hayatı seri bir şekilde düzenlenmiştir.

Fethin hemen ardından Üsküp'te de sınır bölgelerinde fethedilen yerlerde açık bir şekilde askeri ve geçici karakter taşıyan uçbeyliği kuruldu. Üsküp'ün yönetimi, Osmanlı toprağı haline geldiği 1392'den 1463'e değin bu müstakil yapısını korudu (Stoyanovski 1974, 216-217). 1414'e kadar uç beyliği Paşa Yiğit Bey'de iken bu tarihte ölümünün ardından evlatlı̆̆ olarak bilinen İshak Bey uç beyi olmuştur. İshak Bey'in ölümünden sonra İsa Bey yönetimi devralmıştır. İsa Bey'in ölümünden sonra ise sahip olduğu müstakil yapı ortadan kaldırılarak 1463 'ten sonra Paşa Sancağı'na bağlı bir “Kaza”ya dönüştürülmüştür (İnbaşı 1995, 26-27). 1530 tarihli Rumeli Vilayeti'ne ait muhasebe kaydında Paşa Livası'na bağlı 19 sağ kol kazasından biri olarak kaydedilen Üsküp (370 Numaralı Muhasebe-i Vilayet-i Rum-i̇li Defteri (937/1530) 2001, 4-5) 1542 tarihli tahrir defterinde Paşa Sancağı'na bağlı bir nahiye olarak kaydedilmiştir. Nefs-i Üsküp tabiri ile şehir merkezi de belirtilen Üsküp'e tabi olan 216 karye kaydedilmiştir (Çağ 2004, 29). 1544'te Rumeli Eyaleti'ne bağlı bir Sancak olan Üsküp'e (Dede 2015, 11), eskiden Paşa Sancağı'na bağlı olan Kalkandelen, Pirlepe, Üsküp ve Kırçova kadılıklarının bağlandığı bilinmektedir (Stoyanovski 1974, 229). 1630'da halen sancak statüsünü korumaktaydı (Turan 1963, 201-232). 1668/1669'daki kayıtlardan Üsküp Sancağı'na Köprülü kazası ile Morihova nahiyesinin de eklendiği anlaşılmaktadır (Stojkoy 1970, 211-212).

Üsküp, 1689-1690 arasındaki Avusturya işgalinin ardından tekrar Osmanlı hâkimiyetine dâhil edilmiştir. Avusturya işgali altındayken General Piccolomini'nin veba korkusu ya da askeri sebeplerle Üsküp'ün yakılmas1 emrini vermesinden sonra Üsküp sadece iktisadi olarak değil etnik açıdan da değişime uğramıştır. İşgal öncesi 60.000 olduğu düşünülen nüfusu XVII. yüzyılın sonlarında 6.000'e düşmüştür (Hoca 1984, 124; Üsküp'te 1689'da Avusturya tarafindan işgal edildiği sırada veba salgını olduğu anlaşılmaktadır. Ancak şehrin yakılması emrinin bu veba salgınından ziyade askeri amaç taşıdığı bilinmektedir (Kul 2013, 11-15).

1730'da Üsküp, Rumeli Eyaleti'ne bağlı bir liva olarak görünmektedir (Başar 1997, 17). XIX. yüzyılın başında Selanik, Köstendil ve Sofya'nın arasında yer alan Üsküp Livası'nın Üsküp, Kalkandelen, Kırçova, Köprülü, Pirlepe, Kıvırcık, Kırnık ve Kaçanik isimlerinde 8 kazası bulunmaktaydı (İnciciyan \& Andreasyan 1973-74, 53). 1833'te bünyesinde 47 mahalle, 155 köy ile Kaçanik nahiyesi ve ona bağl1 20 köyü kapsayan bir idarî birimdir.

Osmanlı yönetimine dâhil olduğu zamandan itibaren idari açıdan geçirdiği değişimi izah etmeye çalıştığımız Üsküp Sancağı'na bağlı kazalardan biri olan Üsküp Kazası'nda yapılan nüfus sayımı sonucunda 1832'de Üsküp Kazası mufassal nüfus defterleri oluşturulmuştur. 1833 'de bu mufassal defterlerin icmali hazırlanmıştır. Başbakanlık Osmanlı Arşivi'nde bulunan NFS.d.5624 kodlu defter "Üsküp, Kalkandelen ve Kırçova Kazaları'nda mutavattın ehl-i İslam ve reaya ve Yahudiyân ve Kıbtîyân ve Yabancıların defteri mufassalları icmâlidir" başlı̆̆ını taşımaktadır. Defterdeki Üsküp Kazası'na ilişkin bilgiler kullanılarak tek bir tablo oluşturulmuştur (Tablo 1-2). Çalışmanın amacı; Üsküp Kazası'nda yaşayan dinî grupların toplam nüfusunu belirlemekle ve dinî grupların yerleşim yerlerine göre nüfus dağılımlarını tespit edebilmektir. Ayrıca gayrimüslim nüfusun ödemekle yükümlü oldukları cizye vergisinin türleri de defterde yer alan verilerdendir. Bu verilerden yola çıarak Üsküp Kazası'nda yaşayan gayrimüslim tebaanın gelir seviyesi de ortaya çıkarılmıştır. 


\section{3'te Üsküp Şehri}

Üsküp şehrinde $1455^{\prime}$ de $31,1468^{\prime}$ de $45,1529^{\prime}$ da 64,1569 'da 67 mahalle bulunmaktayd1. 1544 'den sonra gayrimüslim mahalleleri azalma seyrindeyken Müslümanlarla meskûn mahallelerin sayısında artı̧̧ gözlenmekteydi (İnbaş1 1995, 41). 1629'da 62, 1686'da 64 mahalleye sahip olan Üsküp şehrinde 18. yüzyılın başında 68 mahalle tespit edilmiştir (Kul 2013, 72). Evliya Çelebi seyahatnamesinde Üsküp'ten 70 mahalleli bir şehir olarak bahsetmektedir (Evliya Çelebi 2013, 5/356). Üsküp'ün mahalle sayısı daha sonraki dönemlerde azalmıştır.

Buna göre 47 mahalleden müteşekkil olan Üsküp şehrinin en büyük mahallesi İbn Payko'dur. İbn Payko'da 154 hanede 360 kişilik nüfus yaşamaktadır. En küçük mahalle ise 5 haneden müteşekkil olup 14 nüfusla Hacı Kasım Mahallesi'dir. 21 mahallede sadece Müslüman nüfus bulunmaktadır. Bunlar; Hoca Şems, Muradiye, İbn-i Çebni, Hüdaverdi, İbn-i Bahri, Hatuncuklar, İshakiye, Hacı Gazi, Hacı Taceddin, Kara Kapucu, Hacı Muhyiddin, Kasım Gazi, İsmail Voyvoda, Emir Hoca, Hazinedar İsmail, İbn-i Şahin, Hacı Kasım, Oruç Paşa, Pazarbaşı, Muhyiddin Çelebi, Hacı Hayreddin Mahalleleridir. Kaleiçinde de sadece Müslümanlar yaşamaktadırlar (BOA., NFS.d., 5624, 1). Bahse konu 21 mahalle ve kaleiçinde toplam 523 hane ve 1113 nüfus tespit edilmiştir. Üsküp şehrinin bütün mahallelerinde meskûn toplam 1236 Müslüman hane bulunmaktadır. Burada sayılan Müslüman nüfus ise 2692'dir. Müslüman nüfusun \%59'u diğer gayrimüslim reaya ve Kıbtîlerle ortak bir yaşam alanına sahipken \% 41'i kendi dinlerine mensup insanlarla bir arada yaşamaktadır.

Üsküp'ün 25 mahallesinde gayrimüslim yerleşimi bulunmaktadır. Bunlar; Cami-i Atik, Eyne Bey, İbn-i Ömer, Hacı Balaban, Yiğit Paşa, Cedid İsa Bey ve Şeyh Ramazan, Hacı Yunus, Kapucu Hamza, İskender Gazi, İbn-i Kocacık, Kebir Mehmet Çelebi, İbn-i Muhtesib, İbn Payko, Hacı Lala, Debbağ Şahin, Katip Şahin, Dervişan, Gazi Menteş, Haraccı Selahaddin Mahalleleridir. Cami-i Atik, Eyne Bey, İbn-i Ömer, Hacı Balaban, Cedid İsa Bey ve Şeyh Ramazan, Hacı Yunus, Kapucu Hamza, İbn-i Kocacık, Kebir Mehmet Çelebi, Dervişan Mahalleleri her ne kadar Müslümanlarla Hıristiyanların ortak yaşadıkları mahalleler gibi görünüyorsa da Hıristiyanların çok az bir yoğunluğa sahip olduğu nüfus icmal defterinden anlaşılmaktadır. Buna karşın Haraccı Selahaddin Mahallesi'nde de Hıristiyan hane ve nüfus sayısı Müslümanlara göre baskın durumdadır. Sadece gayrimüslimlerin yaşadıkları 5 mahalle bulunmaktadır. Bunlar Yahudiyan, Şevketli, Kadı Çayırı, Yeni Mahalle ve Bülbül Zaim Mahalleleridir (BOA., NFS.d., 5624, 6). Üsküp şehrinde 1705 gayrimüslim yaşamaktadır. Bunların 73 hanede yaşayan 144 kişisi Yahudi, 165 kişisi de misafireten Üsküp merkezinde ikamet eden Hıristiyanlardır. Diğer gayrimüslim ve Müslüman mahallelerinde, köylerde bulunmayan Yahudiler, Üsküp'te sadece Yahudiyan Mahallesi'nde ikamet etmektedirler. Hiristiyan nüfusun \%79'u Müslümanlarla ortak yaşam sürdürürken sadece \%21'i Hıristiyan mahallelerde yaşamaktadırlar.

Hıristiyanlardan çarşıda yaşamlarını sürdürenler de bulunmaktadır. Nüfus icmal defterinde bu kişilerin sayılarına yer verilmiş lâkin hane belirtilmemiştir. Tüccar hanları bu gibi bekâr yaşayanlar için bir seçenek olduğu gibi Evliya Çelebi'nin de Üsküp'teki varlıklarından bahsettiği bekâr odaları (Üsküp'te 13 tane bekâr odası bulunduğunu aktaran Evliya Çelebi bu odalarda ikâmet edenlerin tümünün ehl-i hıref bekârlardan oluştuğunu yazmıştır. Evliya Çelebi 2013, 5/359) veyahut çarşıda dükkânların üstündeki odalarda yaşadıklarını düşündüğümüz insanlar (bekar odaları ve işlevleri için bk. Çokuğraş 2013, 29-35) icmal defterinde esnaf grubu olarak gösterilmiştir. Hane sayısı belirtilmediği için bu tespiti yaptığımız grup, gayrimüslimlerin çalıştıkları esnaf dalları hakkında da bilgiye ulaşmamızı sağlamaktadır. Simitçi, ekmekçi, kasab, bezci, iplikçi, haftancı, pabuçcu, moytabcı, semerci, urganc1, terzi, kuyumcu, kürkçü ve mumcu olarak geçindikleri icmal defterinden anlaşılmaktadır (BOA., NFS.d., 5624, 6). 
Gayrimüslimlerin hane ve nüfus bilgileri dışında defterden öğrenebildiğimiz bir diğer bilgi de ödedikleri cizye türleridir. Üsküp şehrinde cizye mükelleflerinden (Kıbtî Müslümanlar ve misafireten mûkim Kıbtîler bu hesabın dışında tutulmuştur. Zira incelenen icmal defterinde Kıbtî Müslümanların cizyeleri diğer gayrimüslimlerdeki gibi "âlâ, evsât, ednâ" olarak değil sadece "dâhil-i cizye" olarak sinıflandırılmıştır. Misafir olarak Üsküb'de yerleşik olan Kıbtî Hıristiyanların da ödedikleri cizye türü listede gösterilmemiştir. \% 7,01'i âlâ, \% 47,08'i evsât ve $\% 25,24$ 'ü ise ednâ türünde cizye ödemektedirler. \%20,58'i ise cizyeden muaf olanlar ve henüz cizye ödeme yaşına gelmemiş çocuklardan oluşmaktadır. Cizye türünün belirlenmesinde kişinin mevcut geliri temel ölçüt olduğundan buna göre Üsküp şehrinde yaşayan gayrimüslimlerin yarısından fazlasının orta ve üst gelir düzeyine sahip olduğu anlaşılmaktadır.

Kıbtî Müslümanlar, Üsküp şehrinde Cedid İsa Bey, Şeyh Ramazan, Gazi Menteş ve Tophane mahallelerinde, güherçile imalinde, menzilhanede, çilingir, canbaz ve kaşıkçı göçebesi olarak kaydedilen toplam 117 hanede 343 kişidir. Bunların 240'1 cizye mükellefiyken 100'ü çocuk, 3'ü de cizyeden muaftır. Hacı Yunus ve Kâtip Şahin mahallelerinde, mahallelerin dışında göçebe olarak da kaydedilen Kıbtî reaya toplamda 24 hanede 59 kişi olarak deftere kaydedilmiştir. Kıbtî reayanın 29'u evsât, 10’u ednâ türünde vergiye tabidir (BOA., NFS.d.5624, 5).

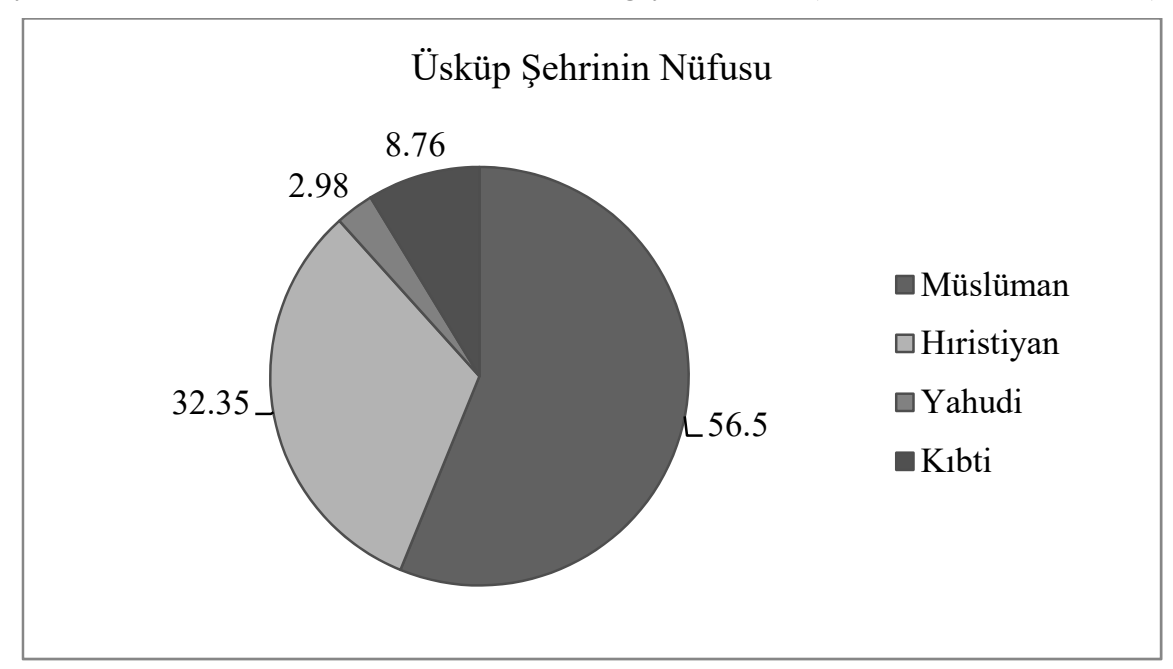

Yukarıda ayrıntılandırılan Üsküp şehrinin genel nüfusu 4918 kişidir. Grafikte de görüldüğü üzere \%56,50’si Müslüman, \% 32,35 Hıristiyan, \%2,98 Yahudi, \%8,76’s1 Kıbtî’lerden oluşmaktadır.

\section{Üsküp Kazası'na Bağlı Kırsal Alan}

Nüfus icmal defterinde Üsküp Kazası'na bağlı köyler, bulundukları bölgelere göre Çayırova, Karadağ, Karşıyaka ve Derbend kollarına ayrılarak listelenmiş̧tir. Bunun yanında Üsküb'e bağlı Kaçanik nahiyesinin nüfusu da ayrıca belirtilmiştir.

1. Çayırova Kolu: Günümüzde Üsküp şehrinin kuzeydoğusuna isabet eden Çayırova kolunda 56 köy bulunmaktadır. Bu köylerden 19'unda Müslümanlar yaşamaktadır. Bugün Üsküp Kumanova yolunda olan Orlançe, Moyançe ve Bare köyleri sadece Müslümanlar tarafından iskân edilmiş vaziyettedir. Bu üç köy dışında kalan bütün köyler gayrimüslim reayanın başka ifade ile Hıristiyanların yaşadığı köylerdir. 13 köyde Kıbtî Müslümanlar, 15 köyde de Kıbtî reaya bulunmaktadır. Çayırova kolunda misafir olarak gelip yerleşenler de dâhil olmak üzere toplam 6011 nüfus yaşamaktadır. Bu nüfusun \% 17.46's1 Müslüman, \%77,69'u Hıristiyan, \% 4,84'ü de Kıbtî’lerden oluşmaktadır. 
Hıristiyan reayanın ödedikleri cizye türüne göre dağılımları ise şu şekildedir; \%0.77 âlâ, \%49.91 evsât, \%21.07 ednâ. Nüfusun \%28,25'ini ise cizyeden muaf olanlar ve henüz cizye mükellefi olmayan çocuklar oluşturmaktadır. Güreler-i Bâlâ (BOA., NFS.d.5624, 1,5,6,12), Çayırova kolunda nüfus hacmi açısından en büyük köy olduğu gibi Müslüman, Hıristiyan reaya, Kıbtî Müslüman ve Kıbtî Hıristiyanlarla meskûn kozmopolit bir köydür. Toplamda 381 kişinin yaşadığı Güreler-i Bâlâ nüfus açısından en büyük köy iken Dokumya (?) karyesi 5 hane ve 9 kişilik nüfusuyla bu kolun en küçük köyüdür.

2. Karadağ Kolu: Günümüzde Üsküp şehrinin kuzey ve kuzey-batısında kalan Karadağ kolunda 32 köy mevcuttur. 9 köy Müslümanlar, 27 köy Hıristiyanlar, 3 köy Kıbtî Müslüman ve 2 köy de Kıbtî Hıristiyanlar tarafından iskân edilmiştir. 3349 nüfuslu Karadağ kolunun yaklaşık \%19.46'unu Müslümanlar, \%79.57'sini Hıristiyanlar ve \%1.25'ini Kıbtîler oluşturmaktadır. Hıristiyanların \%0.90'1 âlâ, \%47.16's1 evsât, \%20.63'ü ednâ türünde cizye ödemektedirler. \% 31,31'i çocuk ve cizyeden muaf olanlardır. Nüfus açısından bakıldığında Karadağ kolunun en büyük köyü 452 kişiyle Kucevişte, en küçük köy ise 10 kişiyle Orizar-i Zîr köyüdür (BOA., NFS.d.5624, 1,5,7,12).

3. Karşıyaka Kolu: Vardar Nehri’nin güneybatı yakasında 18. yüzyıla kadar ciddi bir yerleşim söz konusu olmamıştır. "Karşıyaka" olarak adlandırılan (Abaz 2012, 24) bu kolda 59 köy bulunmaktadır. 21 köyde sadece Müslümanlar, 18 köyde sadece Hıristiyanlar yaşarken 20 köy ortak yaşam alanı haline gelmiştir. 5040 kişinin yaşadığı Karşıyaka kolunun yaklaşık \% 45.01'i Müslüman, \% 52.98'i Hıristiyan, \% 1.99'u ise Kıbtîlerden oluşmaktadır. Karşıyaka kolunun en büyük köyü 375 kişilik nüfusa sahip Hıristiyan reayanın yaşadığı Draçova köyüdür. En küçük köy de 3 haneli Hacova köyüdür. Hıristiyanların \% 1.53'ü âlâ, \% 52.18'i evsât, \% 16.87 'si ise ednâ sınıfında cizye ödemektedirler. Geri kalan nüfus çocuklar ve cizye muafiyeti bulunanlardır (BOA., NFS.d.5624, 1,4,5,7,12).

4. Derbend Kolu: Bugün Üsküp'ün batısında yer alan Derbend kolunda nüfus icmal defterine göre 8 köy bulunmaktadır. Bukovik ve Glumova dışındaki diğer köylerde Müslümanlar haricinde yaşayan yoktur. Rahçe köyü 237 nüfusla Derbend kolunun en büyük köyüdür. Derbend kolunda 18 Hıristiyan'la birlikte toplam 1252 kişi yaşamaktadır.

5. Kaçanik Nahiyesi: Üsküp Kazası'na bağlı bir nahiye olan Kaçanik günümüzde Kosova sınırları içinde yer almaktadır. Nüfus icmal defterine göre sadece bir Hıristiyan hanenin bulunduğu Sopotniçe-i Sagir karyesi dışında nüfusu tamamen Müslümanlardan oluşmaktadır. Kaçanik'in kasabasında 55 hane 164 nüfus yaşamaktadır. Kaçanik nahiyesine bağlı 20 karye bulunmaktadır. Toplam nüfusu 1863 olan Kaçanik nahiyesinde Biçofçe, Sopotniçe-i Kebir, Gabriçe, İlyaslar, Kaçanik-i Atik ve Sopotniçe-i Sagir karyelerinde Kıbtî Müslümanlar da ikamet etmektedirler. En büyük yerleşim birimi ise 185 nüfuslu İsnegova karyesidir.

\section{Sonuç}

Üsküp Kazası'nda 1833 tarihli nüfus tahririnin sonuçlarına göre toplam 22.452 kişi yaşamaktadır. Bu nüfusun \% 51,63’ü Hıristiyan reaya, \% 43,71'i Müslüman, \% 2,79’u Kıbtî Müslüman, \% 1,21 Kıbtî Hıristiyan, \%0,65'i de Yahudilerden oluşmaktadır.

Derbend kolu ve Kaçanik nahiyesi hemen hemen tamamen Müslümanlar tarafindan iskân edilmişken Çayırova'nın ve Karadağ kolunun Hıristiyanların daha yoğun yaşadıkları bölgeler olduğu anlaşılmaktadır. Üsküp şehir merkezi ile Karşıyaka kolu Müslümanlarla Hıristiyanların ortak yaşam alanı haline getirdikleri yerleşim birimleri olarak karşımıza çıkmaktadır.

Yahudiler şehir merkezinde Vardar Nehri'nin kuzeyi ile Üsküp Kalesi'nin güneyinde bulunan tek bir mahalle dışında Üsküp Kazası'nda anlamlı bir çoğunluk oluşturacak düzeyde bir 
nüfusa sahip olmadıkları görülmektedir.

Üsküp'ün nüfusunu oluşturan diğer unsur Kıbtîlerdir. Kıbtîler incelenen defterde Müslim ve reaya olarak ayrı gruplar halinde sayıma tâbi tutulmuşlardır. Defterdeki verilerden yoğunlukla yaşam alanı olarak tercih ettikleri yerlerin Üsküp şehri ile Çayırova kolu olduğu tespit edilebilmektedir.

Nüfus icmal defterinin bir diğer verisi de gelir oranlarına göre verilen cizyedir. $\mathrm{Bu}$ verilerden Üsküp'teki gayrimüslimlerin ödedikleri cizye sınıfı itibariyle maddi anlamda sıkıntı çekmeden hayatlarını devam ettirebildikleri, \%57,09'nun orta ve üst gelir grubuna dâhil olmasından anlaşılmaktadır. 
Tablo 1: H. 1248 Nüfus Tahririnin Sonuçları ${ }^{1}$

\begin{tabular}{|c|c|c|c|c|c|c|c|c|c|c|c|c|c|c|c|c|c|c|c|c|c|}
\hline \multirow[b]{2}{*}{$\begin{array}{l}\text { Aded-i } \\
\text { Mahallat }\end{array}$} & \multirow[b]{2}{*}{ Mahalleler ve Köyler } & \multicolumn{2}{|c|}{ Müslüman } & \multicolumn{7}{|c|}{ Reaya } & \multicolumn{5}{|c|}{ Kıbtiyan Müslim } & \multicolumn{6}{|c|}{ Kıbtiyan Reaya } \\
\hline & & 勇 & 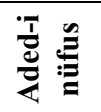 & 焉言 & 音 & 经 & 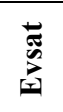 & 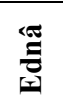 & 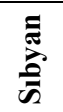 & $\bar{E}$ & 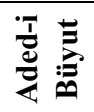 & 窇 & 通 & $\frac{\bar{\pi}}{\overline{\vec{\pi}}}$ & $\bar{\Sigma}$ & 音 & 空 & 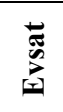 & 㸓 & $\begin{array}{l}\bar{\pi} \\
\frac{\pi}{3} \\
\frac{\pi}{n}\end{array}$ & $\stackrel{\bar{E}}{\bar{E}}$ \\
\hline & Derun-1 Kala da & 1 & 5 & & & & & & & & & & & & & & & & & & \\
\hline 1. & Mahalle-i Hoca Şems & 11 & 29 & & & & & & & & & & & & & & & & & & \\
\hline 2. & Mahalle-i Camii-i Atik & 47 & 113 & 1 & 3 & & 1 & & 2 & & & & & & & & & & & & \\
\hline 3. & Mahalle-i Muradiye & 9 & 23 & & & & & & & & & & & & & & & & & & \\
\hline 4. & Mahalle-i Eyne Bey & 17 & 44 & 4 & 12 & 1 & 4 & 2 & 5 & & & & & & & & & & & & \\
\hline 5. & Mahalle-i İbn-i Çebni & 27 & 64 & & & & & & & & & & & & & & & & & & \\
\hline 6. & Mahalle-i İbn-i Ömer & 52 & 110 & 1 & 2 & & 1 & & 1 & & & & & & & & & & & & \\
\hline 7. & Mahalle-i Hüdaverdi & 35 & 83 & & & & & & & & & & & & & & & & & & \\
\hline 8. & Mahalle-i İbn-i Bahri & 24 & 48 & & & & & & & & & & & & & & & & & & \\
\hline 9. & Mahalle-i Hatuncuklar & 51 & 100 & & & & & & & & & & & & & & & & & & \\
\hline 10. & Mahalle-i İshakiye & 21 & 52 & & & & & & & & & & & & & & & & & & \\
\hline 11. & Mahalle-i Hacı Gazi & 25 & 72 & & & & & & & & & & & & & & & & & & \\
\hline 12. & Mahalle-i Hacı Balaban & 16 & 36 & 2 & 3 & & 2 & & 1 & & & & & & & & & & & & \\
\hline 13. & Mahalle-i Yiğit Paşa & 37 & 78 & 62 & 155 & 21 & 52 & 49 & 33 & & & & & & & & & & & & \\
\hline 14. & Mahalle-i Hacı Taceddin & 37 & 77 & & & & & & & & & & & & & & & & & & \\
\hline 15. & Mahalle-i Kara Kapucu & 33 & 86 & & & & & & & & & & & & & & & & & & \\
\hline 16. & $\begin{array}{l}\text { Mahalle-i Cedid İsa Bey ma Şeyh } \\
\text { Ramazan }\end{array}$ & 52 & 92 & 6 & 8 & & 6 & & 2 & & 3 & 11 & 8 & 3 & & & & & & & \\
\hline 17. & Mahalle-i Hacı Muhyiddin & 26 & 63 & & & & & & & & & & & & & & & & & & \\
\hline 18. & Mahalle-i Hacı Yunus & 47 & 108 & 2 & 4 & & 1 & 2 & 1 & & & & & & & 2 & 7 & 2 & 3 & 2 & \\
\hline 19. & Mahalle-i Kapucu Hamza & 69 & 134 & 1 & 2 & & 1 & 1 & & & & & & & & & & & & & \\
\hline 20. & Mahalle-i İskender Gazi & 18 & 37 & 11 & 32 & & 12 & 11 & 9 & & & & & & & & & & & & \\
\hline 21. & Mahalle-i İbn-i Kocacık & 51 & 97 & 1 & 2 & & 1 & 1 & & & & & & & & & & & & & \\
\hline 22. & Mahalle-i Kasım Gazi & 55 & 121 & & & & & & & & & & & & & & & & & & \\
\hline 23. & Mahalle-i İsmail Voyvoda & 27 & 63 & & & & & & & & & & & & & & & & & & \\
\hline 24. & Mahalle-i Kebir Mehmed Çelebi & 78 & 177 & 5 & 11 & & 4 & 2 & 5 & & & & & & & & & & & & \\
\hline 25. & Mahalle-i İbn-i Muhtesib & 28 & 61 & 20 & 46 & 3 & 20 & 10 & 12 & 1 & & & & & & & & & & & \\
\hline 26. & Mahalle-i Emir Hoca & 13 & 28 & & & & & & & & & & & & & & & & & & \\
\hline
\end{tabular}

${ }^{1}$ Bu tablo BOA, NFS.d. 5624'den istifade edilerek oluşturulmuştur. 


\begin{tabular}{|c|c|c|c|c|c|c|c|c|c|c|c|c|c|c|c|c|c|c|c|c|}
\hline 27. & Mahalle-i Hazinedar İsmail & 22 & 44 & & & & & & & & & & & & & & & & & \\
\hline 28. & Mahalle-i İbn-i Şahin & 18 & 40 & & & & & & & & & & & & & & & & & \\
\hline 29. & Mahalle-i İbn-i Payko & 41 & 92 & 113 & 268 & 36 & 95 & 72 & 63 & 2 & & & & & & & & & & \\
\hline 30. & Mahalle-i Hacı Lala & 12 & 31 & 6 & 14 & 2 & 7 & 2 & 3 & & & & & & & & & & & \\
\hline 31. & Mahalle-i Hacı Kasım & 5 & 14 & & & & & & & & & & & & & & & & & \\
\hline 32. & Mahalle-i Oruç Paşa & 56 & 130 & & & & & & & & & & & & & & & & & \\
\hline 33. & Mahalle-i Debbağ Şahin & 34 & 73 & 15 & 28 & 4 & 17 & 4 & 3 & & & & & & & & & & & \\
\hline 34. & Mahalle-i Katip Şahin & 29 & 66 & 53 & 121 & 2 & 60 & 36 & 22 & 1 & & & & & & 1 & 2 & 1 & 1 & \\
\hline 35. & Mahalle-i Dervişan & 14 & 24 & 3 & 5 & & 3 & 1 & 1 & & & & & & & & & & & \\
\hline 36. & Mahalle-i Pazarbaşı & 27 & 54 & & & & & & & & & & & & & & & & & \\
\hline 37. & Mahalle-i Muhyiddin Çelebi & 8 & 12 & & & & & & & & & & & & & & & & & \\
\hline 38. & Mahalle-i Hacı Hayreddin & 19 & 21 & & & & & & & & & & & & & & & & & \\
\hline 39. & Mahalle-i Gazi Menteş & 37 & 79 & 50 & 107 & 3 & 55 & 19 & 30 & & 17 & 47 & 34 & 12 & 1 & & & & & \\
\hline 40. & Mahalle-i Haracc1 Selahaddin & 7 & 11 & 128 & 286 & 18 & 124 & 86 & 56 & 2 & & & & & & & & & & \\
\hline 41. & Mahalle-i Yahudiyan & & & 73 & 144 & 9 & 64 & 24 & 47 & & & & & & & & & & & \\
\hline 42. & Mahalle-i Şevketli_ & & & 8 & 18 & 1 & 6 & 7 & 4 & & & & & & & & & & & \\
\hline 43. & Mahalle-i Kadı Çayırı & & & 10 & 24 & & 13 & 6 & 5 & & & & & & & & & & & \\
\hline 44. & Mahalle-i Bülbül Zaim & & & 10 & 20 & & 10 & 5 & 5 & & & & & & & & & & & \\
\hline 45. & Yeni Mahalle & & & 30 & 73 & 4 & 34 & 18 & 17 & & & & & & & & & & & \\
\hline 46. & Mahalle-i Tophane & & & 24 & 57 & & 35 & 12 & 10 & & 15 & 25 & 18 & 7 & & & & & & \\
\hline & Esnaf-1 Simidçi & & & & 12 & & 8 & 3 & 1 & & & & & & & & & & & \\
\hline & Esnaf-1 Etmekçi & & & & 2 & & & 2 & & & & & & & & & & & & \\
\hline & Esnaf-1 Kasab & & & & 3 & 1 & 2 & & & & & & & & & & & & & \\
\hline & Esnaf-1 Bezci & & & & 1 & & 1 & & & & & & & & & & & & & \\
\hline & Esnaf-1 İplikçi & & & & 9 & & 9 & & & & & & & & & & & & & \\
\hline & Esnaf-1 Haftanc1 & & & & 2 & & 1 & 1 & & & & & & & & & & & & \\
\hline & Esnaf-1 Babuççu & & & & 11 & & 10 & 1 & & & & & & & & & & & & \\
\hline & Esnaf-1 Mubtabc1 & & & & 3 & & 3 & & & & & & & & & & & & & \\
\hline & Esnaf-1 Semerci & & & & 3 & & 3 & & & & & & & & & & & & & \\
\hline & Esnaf-1 Urganc1 & & & & 22 & 2 & 15 & 5 & & & & & & & & & & & & \\
\hline & Esnaf-1 Derzi & & & & 12 & & 7 & 5 & & & & & & & & & & & & \\
\hline & Esnaf-1 Kuyumcu & & & & 1 & & & 1 & & & & & & & & & & & & \\
\hline & Esnaf-1 Kürkçü & & & & 12 & & 6 & 6 & & & & & & & & & & & & \\
\hline & Esnaf-1 Mumcu & & & & 2 & & 2 & & & & & & & & & & & & & \\
\hline
\end{tabular}




\begin{tabular}{|c|c|c|c|c|c|c|c|c|c|c|c|c|c|c|c|c|c|c|c|c|c|}
\hline & Güherçile imalinde olan & & & & & & & & & & 17 & 57 & 39 & 18 & & 3 & 7 & 3 & 1 & 3 & \\
\hline & Dekakinde mutavattın & & & & & & & & & & 4 & 12 & 9 & 3 & & & & & & & \\
\hline & Çilingir Göçebesi & & & & & & & & & & 33 & 112 & 76 & 34 & 2 & & & & & & \\
\hline & Canbaz göçebesi & & & & & & & & & & 27 & 69 & 48 & 21 & & 1 & 2 & 1 & & 1 & \\
\hline & Kaşıkcı Eyulah ? Göçebesi & & & & & & & & & & & & & & & 13 & 31 & 18 & 5 & 8 & \\
\hline & Menzilhanede mutavattın & & & & & & & & & & 1 & 10 & 8 & 2 & & 4 & 10 & 4 & 1 & 5 & \\
\hline & Çayırova Kolu & & & & & & & & & & & & & & & & & & & & \\
\hline 1. & Karye-i Kiremitlik & & & 15 & 43 & & 22 & 12 & 9 & & & & & & & & & & & & \\
\hline 2. & Karye-i Macarlu & & & 19 & 52 & & 35 & 7 & 10 & & & & & & & & & & & & \\
\hline 3. & Karye-i Turbarova & & & 10 & 32 & & 16 & 6 & 10 & & 5 & 15 & 10 & 5 & & & & & & & \\
\hline 4. & Karye-i Urumlar & & & 26 & 90 & & 51 & 19 & 20 & & 4 & 13 & 9 & 4 & & & & & & & \\
\hline 5. & Karye-i İdris & 4 & 4 & 15 & 51 & & 31 & 6 & 14 & & 2 & 4 & 2 & 2 & & 1 & 1 & 1 & & & \\
\hline 6. & Karye-i Tahova? & & & 11 & 39 & & 22 & 8 & 9 & & & & & & & & & & & & \\
\hline 7. & Karye-i Ogyançe & & & 14 & 50 & & 19 & 17 & 14 & & 8 & 20 & 14 & 6 & & & & & & & \\
\hline 8. & Karye-i Pakşova & & & 24 & 93 & & 45 & 29 & 19 & & & & & & & & & & & & \\
\hline 9. & Karye-i Tahor & & & 10 & 30 & & 16 & 8 & 5 & 1 & & & & & & & & & & & \\
\hline 10. & Karye-i Novasel & & & 13 & 57 & & 30 & 13 & 14 & & & & & & & & & & & & \\
\hline 11. & Karye-i Blaçe-i miç & & & 27 & 84 & 1 & 38 & 16 & 29 & & & & & & & & & & & & \\
\hline 12. & Karye-i Kojle & & & 73 & 244 & 4 & 128 & 45 & 65 & 2 & & & & & & & & & & & \\
\hline 13. & Karye-i Bihavod? & & & 20 & 64 & & 33 & 13 & 18 & & & & & & & & & & & & \\
\hline 14. & Karye-i Kaplanlı & 4 & 15 & 15 & 68 & & 36 & 16 & 16 & & 1 & 3 & 3 & & & 2 & 7 & 2 & 2 & 3 & \\
\hline 15. & Karye-i Letefçe & & & 15 & 55 & & 24 & 13 & 18 & & & & & & & & & & & & \\
\hline 16. & Karye-i Brezniça & & & 35 & 135 & 1 & 70 & 25 & 39 & & & & & & & & & & & & \\
\hline 17. & Karye-i Gradmançe & & & 10 & 45 & & 18 & 10 & 17 & & & & & & & & & & & & \\
\hline 18. & Karye-i Jidimir? & & & 30 & 131 & 1 & 70 & 31 & 29 & & & & & & & & & & & & \\
\hline 19. & Karye-i Suşiçe-i derbend & & & 68 & 257 & 3 & 133 & 60 & 58 & 3 & & & & & & & & & & & \\
\hline 20. & Karye-i Divle & & & 50 & 185 & 1 & 88 & 35 & 58 & 3 & & & & & & & & & & & \\
\hline 21. & Karye-i Kruşa ? & 28 & 54 & & & & & & & & & & & & & & & & & & \\
\hline 22. & Karye-i Koşinçe & 27 & 101 & 21 & 80 & & 43 & 8 & 27 & 2 & & & & & & & & & & & \\
\hline 23. & Karye-i Güreler-i Zir & 24 & 85 & 19 & 54 & 1 & 31 & 10 & 12 & & 1 & 6 & 2 & 4 & & 3 & 9 & 6 & 2 & 1 & \\
\hline 24. & Karye-i Güreler-i Bala & 68 & 173 & 39 & 155 & & 77 & 30 & 44 & 4 & 1 & 3 & 2 & 1 & & 12 & 40 & 21 & 10 & 9 & \\
\hline 25. & Karye-i İstuden bara & 13 & 39 & 41 & 134 & & 63 & 31 & 39 & 1 & & & & & & 4 & 16 & 5 & 3 & 7 & 1 \\
\hline 26. & Karye-i Rahmanlı & 26 & 104 & 24 & 78 & 1 & 37 & 18 & 21 & 1 & & & & & & & & & & & \\
\hline 27. & Karye-i Ağa & & & 31 & 93 & 3 & 43 & 16 & 31 & & & & & & & 1 & 2 & 1 & & 1 & \\
\hline
\end{tabular}




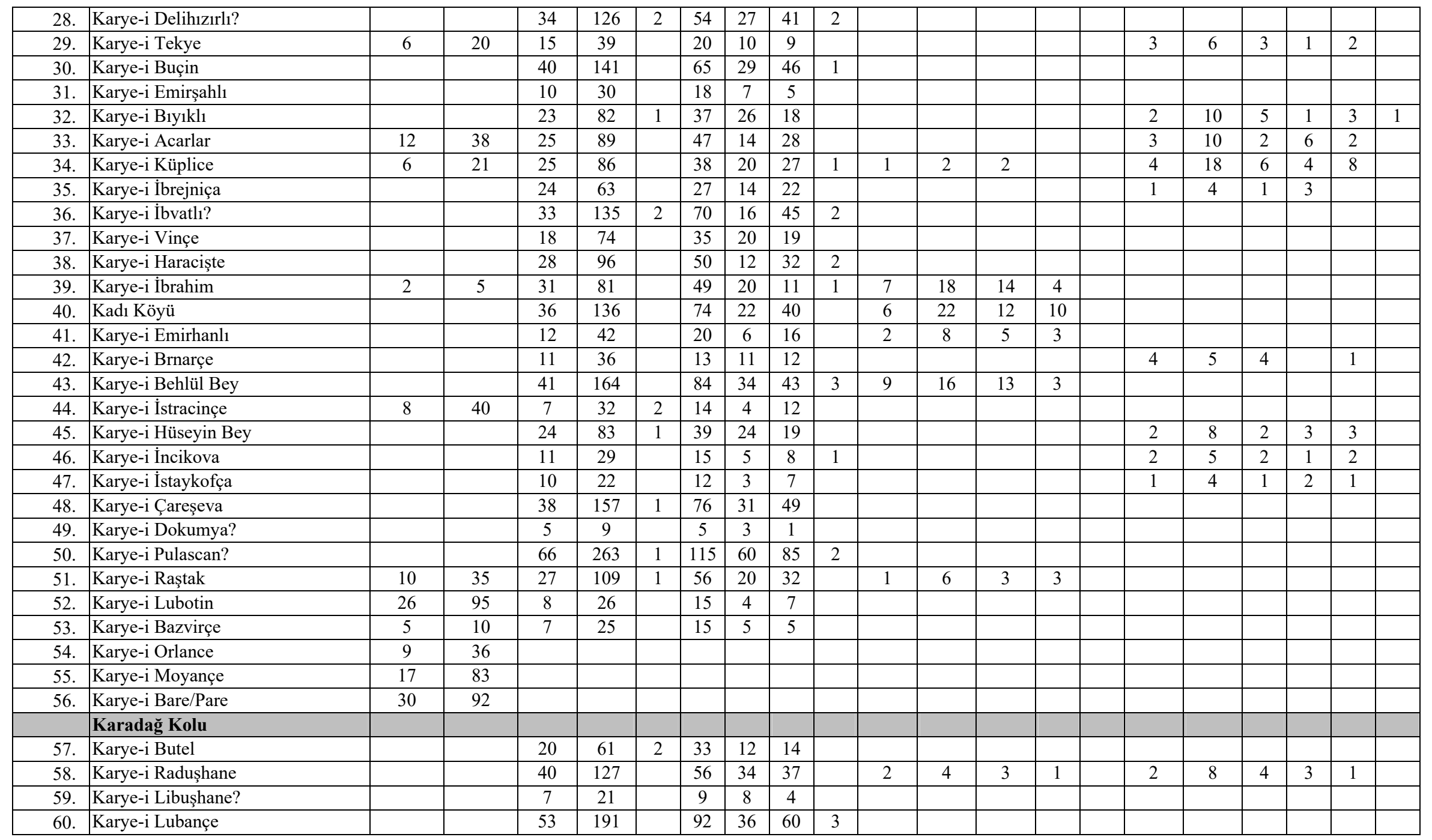




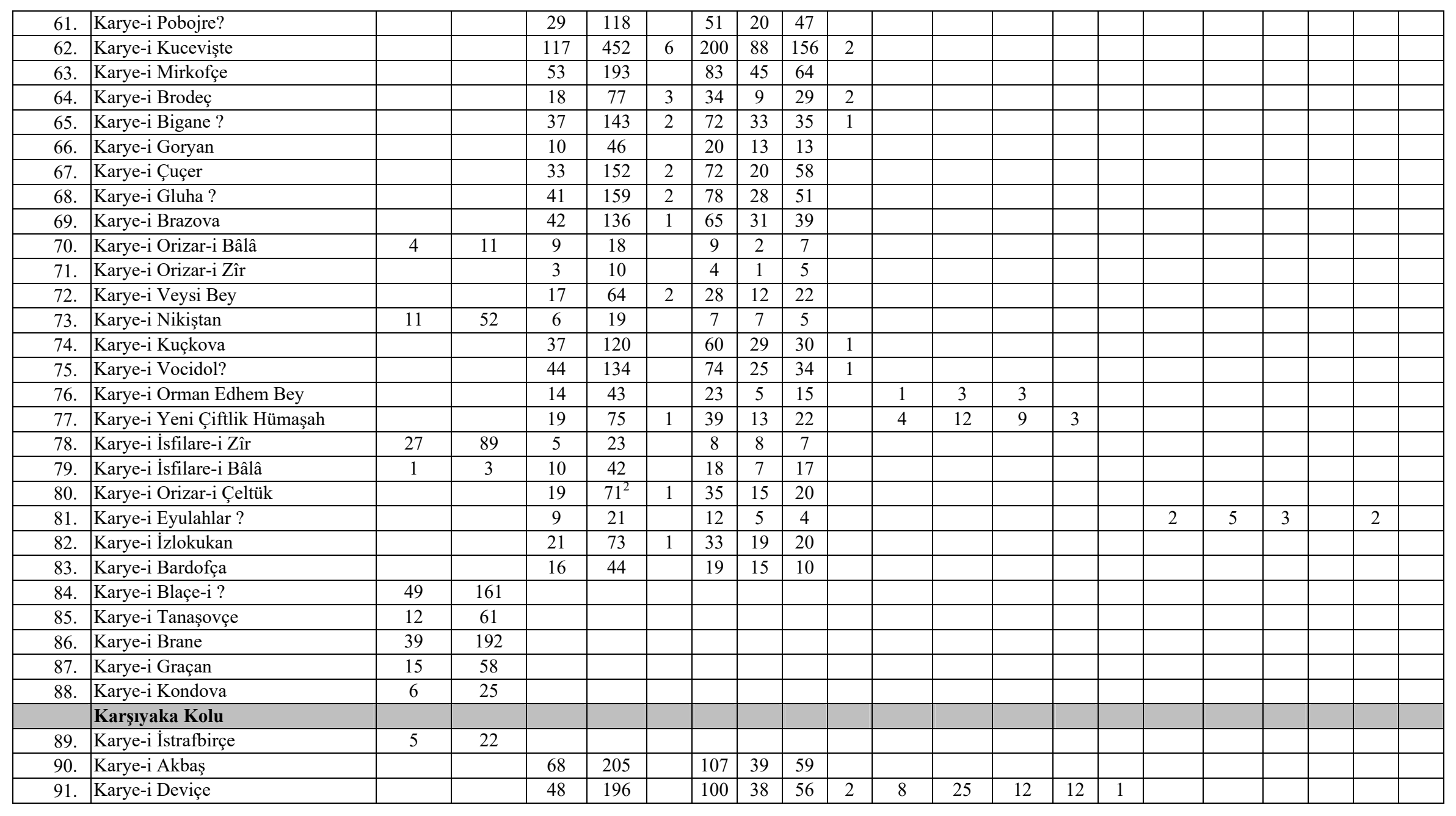

${ }^{2}$ Nfs.d. 5624, s.7'de 70 rakamı verilmiştir. Ancak cizye toplamında 70 değil 71 sonucu çıkar. 


\begin{tabular}{|c|c|c|c|c|c|c|c|c|c|c|c|c|c|c|c|c|c|c|c|c|c|}
\hline 92. & Karye-i Oraşhane & & & 20 & 76 & 1 & 35 & 15 & 24 & 1 & & & & & & & & & & & \\
\hline 93. & Karye-i Zelenikovo & & & 24 & 83 & & 50 & 17 & 15 & 1 & & & & & & & & & & & \\
\hline 94. & Karye-i Gradofçe & & & 32 & 96 & & 45 & 12 & 30 & 9 & & & & & & & & & & & \\
\hline 95. & Karye-i Morane & 29 & 115 & 25 & 83 & 1 & 42 & 14 & 26 & & 3 & 8 & 5 & 3 & & & & & & & \\
\hline 96. & Karye-i Draçova & & & 104 & 375 & 7 & 183 & 78 & 104 & 3 & & & & & & & & & & & \\
\hline 97. & Karye-i Hacova & & & 3 & 3 & & 3 & & & & & & & & & & & & & & \\
\hline 98. & Karye-i Kara Hacı & & & 1 & 2 & & 1 & & 1 & & 1 & 3 & 3 & & & 2 & 7 & 4 & 1 & 2 & \\
\hline 99. & Karye-i Luboşte & & & 15 & 45 & & 26 & 7 & 11 & 1 & & & & & & & & & & & \\
\hline 100. & Karye-i Batinçe & 9 & 31 & 14 & 43 & & 20 & 2 & 21 & & & & & & & & & & & & \\
\hline 101. & Karye-i Varvara & & & 9 & 21 & & 11 & 4 & 6 & & & & & & & & & & & & \\
\hline 102. & Karye-i Suşiçe-i Manastır & & & 7 & 22 & 5 & 10 & 3 & 3 & 1 & & & & & & & & & & & \\
\hline 103. & Karye-i Malcişte & 5 & 23 & 1 & 1 & & 1 & & & & & & & & & & & & & & \\
\hline 104. & Karye-i Osincan & & & 9 & 45 & & 24 & 5 & 15 & 1 & & & & & & & & & & & \\
\hline 105. & Karye-i Patişka & 34 & 111 & 34 & 93 & 5 & 42 & 12 & 34 & & & & & & & & & & & & \\
\hline 106. & Karye-i Pusto Brjaniçe? & & & 30 & 87 & & 56 & 21 & 9 & 1 & & & & & & & & & & & \\
\hline 107. & Karye-i Yabolçe & 6 & 15 & 9 & 16 & & 10 & 2 & 4 & & & & & & & & & & & & \\
\hline 108. & Karye-i Barova & 10 & 51 & 12 & 49 & 2 & 25 & 7 & 14 & 1 & & & & & & & & & & & \\
\hline 109. & Karye-i Govarleva & & & 25 & 76 & 2 & 47 & 14 & 12 & 1 & & & & & & & & & & & \\
\hline 110. & Karye-i Solne-i Bâlâ & & & 24 & 77 & 1 & 38 & 7 & 28 & 3 & & & & & & & & & & & \\
\hline 111. & Karye-i Solne-i zîr & & & 46 & 153 & 2 & 79 & 19 & 48 & 5 & & & & & & & & & & & \\
\hline 112. & Karye-i Dobridol & & & 44 & 125 & 3 & 65 & 22 & 33 & 2 & & & & & & & & & & & \\
\hline 113. & Karye-i Rakotince & 1 & 1 & 25 & 89 & 2 & 60 & 9 & 18 & & & & & & & & & & & & \\
\hline 114. & Karye-i Sopişte & 1 & 1 & 24 & 93 & 2 & 53 & 22 & 12 & 3 & & & & & & & & & & & \\
\hline 115. & Karye-i Usye & & & 22 & 71 & & 39 & 12 & 19 & 1 & & & & & & & & & & & \\
\hline 116. & Karye-i Ekşi Su & & & 9 & 29 & & 13 & 5 & 11 & & & & & & & 1 & 1 & 1 & & & \\
\hline 117. & Karye-i Vodna-i Bâlâ & & & 15 & 51 & & 29 & 8 & 13 & 1 & & & & & & & & & & & \\
\hline 118. & Karye-i Vodna-i Zîr & & & 14 & 56 & & 24 & 6 & 24 & 2 & & & & & & & & & & & \\
\hline 119. & Karye-i Tahta İliçe? & & & 21 & 49 & & 27 & 13 & 9 & & & & & & & 3 & 7 & 4 & 2 & 1 & \\
\hline 120. & Karye-i Nerez & 15 & 64 & 30 & 94 & 6 & 41 & 10 & 37 & & & & & & & & & & & & \\
\hline 121. & Karye-i Şişova & 8 & 31 & 20 & 80 & & 42 & 13 & 25 & & & & & & & & & & & & \\
\hline 122. & Karye-i Hüseyin Şah & 2 & 9 & 20 & 49 & & 27 & 8 & 14 & & & & & & & 6 & 15 & 7 & 5 & 3 & \\
\hline 123. & Karye-i Matka & 10 & 41 & 8 & 23 & & 11 & 2 & 10 & & & & & & & & & & & & \\
\hline 124. & Karye-i İsmesniça & 15 & 28 & & & & & & & & & & & & & & & & & & \\
\hline 125. & Karye-i Gumalova & 24 & 45 & & & & & & & & & & & & & & & & & & \\
\hline
\end{tabular}




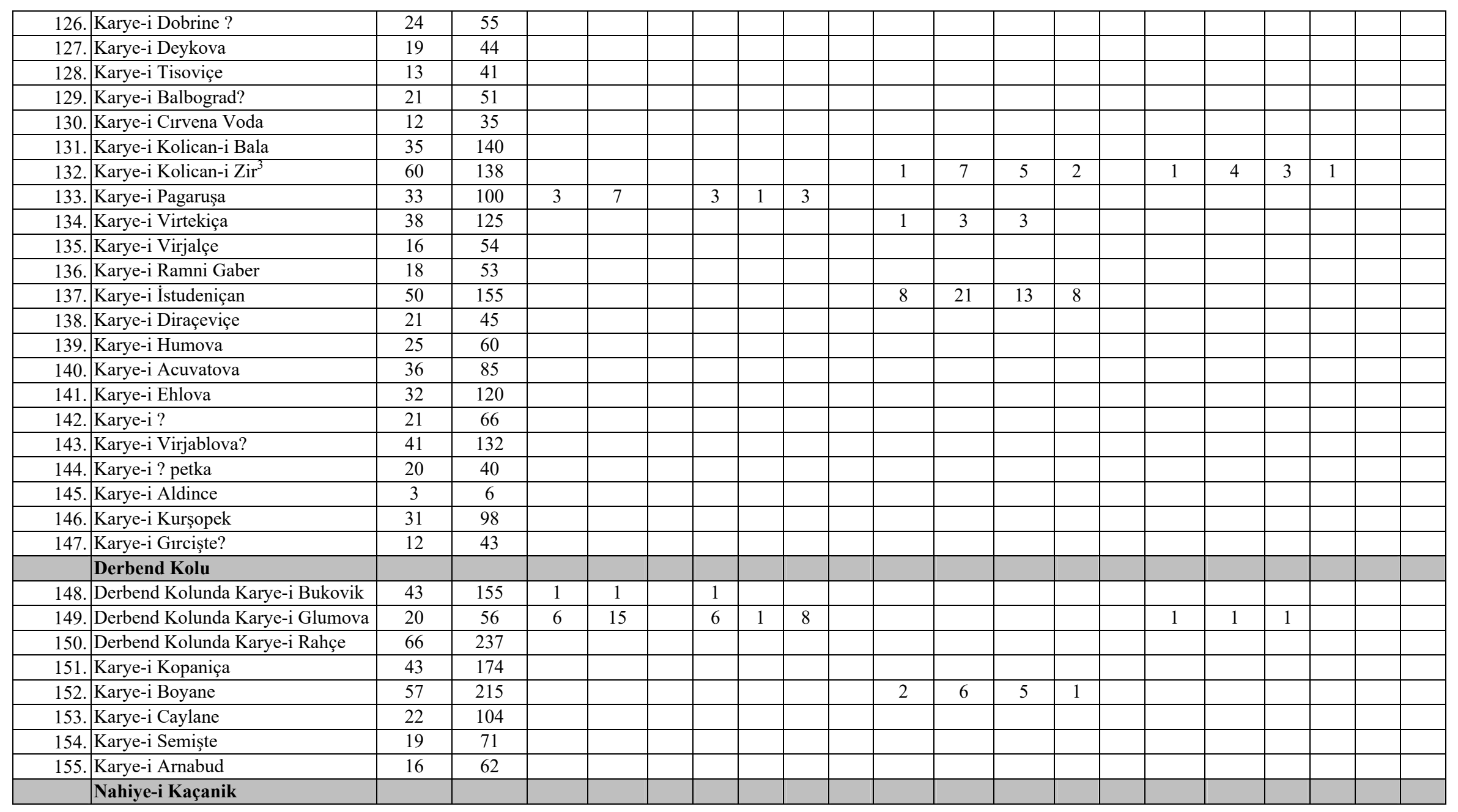

${ }^{3}$ N.FS.d.5624, s.5’te sadece “Karye-i Kolican” olarak geçmektedir. 


\begin{tabular}{|c|c|c|c|c|c|c|c|c|c|c|c|c|c|c|c|c|c|c|c|c|c|}
\hline 156. & Nahiye-i Kasaba-i Kaçanik & 55 & 164 & & & & & & & & & & & & & & & & & & \\
\hline 157. & Karye-i Biçofçe & 27 & 127 & & & & & & & & 1 & 4 & 1 & 3 & & & & & & & \\
\hline 158. & Karye-i Kavacıkça & 31 & 113 & & & & & & & & & & & & & & & & & & \\
\hline 159. & Karye-i Pustenik? & 15 & 73 & & & & & & & & & & & & & & & & & & \\
\hline 160. & Karye-i Roynova & 10 & 38 & & & & & & & & & & & & & & & & & & \\
\hline 161. & Karye-i Nikofçe & 8 & 25 & & & & & & & & & & & & & & & & & & \\
\hline 162. & Karye-i Dimçe & 8 & 25 & & & & & & & & & & & & & & & & & & \\
\hline 163. & Karye-i Bob & 10 & 47 & & & & & & & & & & & & & & & & & & \\
\hline 164. & Karye-i Gurgedol & 15 & 82 & & & & & & & & & & & & & & & & & & \\
\hline 165. & Karye-i Pale Vodayniçe & 9 & 38 & & & & & & & & & & & & & & & & & & \\
\hline 166. & Karye-i Virdomçe & 4 & 19 & & & & & & & & & & & & & & & & & & \\
\hline 167. & Karye-i Nekafçe & 5 & 33 & & & & & & & & & & & & & & & & & & \\
\hline 168. & Karye-i Palvegraçe & 32 & 122 & & & & & & & & & & & & & & & & & & \\
\hline 169. & $\begin{array}{l}\text { Karye-i Sopotniçe-i Kebirde } \\
\text { Dere Kabilesi }\end{array}$ & 7 & 32 & & & & & & & & & & & & & & & & & & \\
\hline & Karye-i mezburda Doğan Kabilesi & 13 & 67 & & & & & & & & & & & & & & & & & & \\
\hline & Karye-i mezburda Oymişte Kabilesi & 10 & 41 & & & & & & & & & & & & & & & & & & \\
\hline & Karye-i mezburda Vata Kabilesi & 16 & 65 & & & & & & & & & & & & & & & & & & \\
\hline & $\begin{array}{lll}\begin{array}{l}\text { Karye-i } \\
\text { Mahallesi }\end{array} & \text { Mezburda } & \text { Gabiriçe } \\
\end{array}$ & 8 & 41 & & & & & & & & & & & & & & & & & & \\
\hline & Karye-i mezburda Raka Mahallesi & 24 & 68 & & & & & & & & 3 & 5 & 5 & & & & & & & & \\
\hline 170. & Karye-i Gabriçe & 19 & 79 & & & & & & & & 1 & 1 & 1 & & & & & & & & \\
\hline 171. & Karye-i İlyaslar & 7 & 36 & & & & & & & & 1 & 2 & 2 & & & & & & & & \\
\hline 172. & Karye-i İslatna & 22 & 110 & & & & & & & & & & & & & & & & & & \\
\hline 173. & Karye-i Dromyak? & 4 & 19 & & & & & & & & & & & & & & & & & & \\
\hline 174. & Karye-i Kaçanik-i Atik & 26 & 79 & & & & & & & & 2 & 2 & 2 & & & & & & & & \\
\hline 175. & Karye-i Sopotniçe-i sagir ${ }^{4}$ & 28 & 96 & 1 & 1 & & & 1 & & & 11 & 24 & 12 & 12 & & & & & & & \\
\hline 176. & Karye-i İsnegova & 58 & 185 & & & & & & & & & & & & & & & & & & \\
\hline TOPLAM & & 3280 & 9721 & 3475 & 11425 & 196 & \begin{tabular}{|l|}
5607 \\
\end{tabular} & 2332 & 3203 & 87 & 215 & 609 & 415 & 190 & 4 & 87 & 252 & 118 & 60 & 72 & 2 \\
\hline
\end{tabular}

Tablo 2: Üsküp Kasabası ve kurrasında misafireten mukim yabancı tablosu

${ }^{4}$ N.FS.d.5624, s.7'de “Üsküb Kasaba ve Kurrasında mütemekkin reaya nüfusu defter-i mufassalının İcmali” tablosunda bu köy “Kaçanik’te Karye-i Sopotniçe” olarak yer almıştır. 


\begin{tabular}{|c|c|c|c|c|c|c|c|c|c|c|c|}
\hline \multirow[t]{2}{*}{ Esamiha-i Mahallat ve Kurra } & \multicolumn{6}{|c|}{ Misafireten mukim yabancı Reaya } & \multirow{2}{*}{$\begin{array}{c}\begin{array}{c}\text { Misafireten mukim yabancı } \\
\text { Ehl-i İslam }\end{array} \\
\end{array}$} & \multicolumn{4}{|c|}{$\begin{array}{c}\text { Misafireten mukim yabancı Kıbtî } \\
\text { Müslim ve Kıbtî Reaya }\end{array}$} \\
\hline & 突 & $\stackrel{\leftarrow}{\gtrless}$ & 穿 & 絰 & 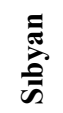 & $\stackrel{\Xi}{E}$ & & 突 & 音 & $\frac{\Xi}{\frac{\pi}{6}}$ & $\stackrel{\Xi}{E}$ \\
\hline Yahudiyan der şehir & 3 & 2 & 1 & & & & & & & & \\
\hline Mahalle-i Yiğit Paşa & 11 & 2 & 7 & 2 & & & & & & & \\
\hline Yeni Mahalle & 3 & & 1 & 2 & & & & & & & \\
\hline Mahalle-i Lala & 1 & & & 1 & & & & & & & \\
\hline Mahalle-i Eyne Bey & 2 & & & 2 & & & & & & & \\
\hline Mahalle-i Hacı Gazi & 1 & & & 1 & & & & & & & \\
\hline Mahalle-i İbn Ömer & 5 & 1 & 3 & 1 & & & & & & & \\
\hline Mahalle-i Katib Şahin & 1 & & 1 & & & & & & & & \\
\hline Mahalle-i Gazi Menteş & & & & & & & & 2 & 2 & & \\
\hline İbn Payko Mahallesinde Şeyh Mehmed Efendi Tekyesinde & & & & & & & 7 & & & & \\
\hline Hac1 Taceddin Mahallesinde vaki hamamda & & & & & & & 4 & & & & \\
\hline Alaca Medresede & & & & & & & 4 & & & & \\
\hline Menzilhane $^{5}$ & & & & & & & & 21 & 18 & 2 & \\
\hline Derun-1 Kal'a & 6 & & 4 & 2 & & & 25 & & & & \\
\hline Kal'ada Sekban Neferâtı & & & & & & & 10 & & & & \\
\hline Kal'ada Saraydaran & & & & & & & 7 & & & & \\
\hline Hane-i Misafirânda Tüfenkçibaşı maiyetinde Sekban Neferâtı & & & & & & & 11 & & & & \\
\hline Misafir Konağında & & & & & & & 14 & & & & \\
\hline Esnaf-1 Meyhaneciyan & 13 & 5 & 8 & & & & & & & & \\
\hline Esnaf-1 Urganciyan & 1 & & & 1 & & & & & & & \\
\hline Esnaf-1 Kuyumcuyan & 10 & 1 & 7 & 2 & & & & & & & \\
\hline Esnaf-1 Doğramaciyan & 1 & & 1 & & & & & & & & \\
\hline Esnaf-1 Derziyan & 13 & & 9 & 4 & & & & & & & \\
\hline Efnaf-1 Mumcuyan & 1 & & 1 & & & & & & & & \\
\hline Esnaf-1 Semerciyan & 14 & & 10 & 4 & & & & & & & \\
\hline
\end{tabular}

${ }^{5}$ Menzilhane'de 10 Kıbti Müslim 11 Kıbti Reaya ikamet etmektedir. 3 sıbyan haricinde tümü Cizye mükellefi olarak kaydedilmiştir. 


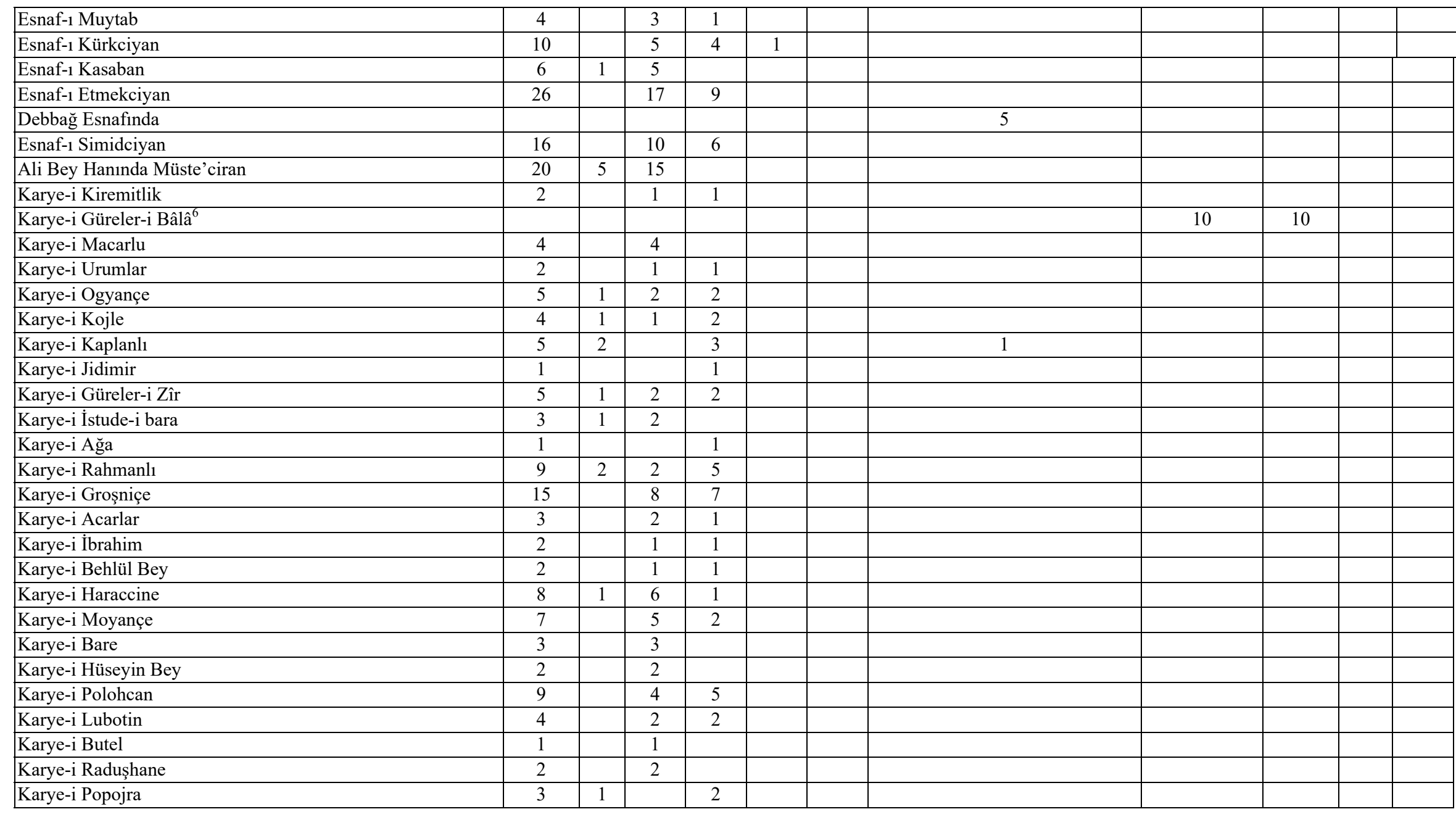

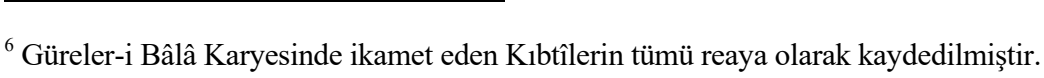




\begin{tabular}{|l|l|l|l|l|l|l|l|l|}
\hline Karye-i Kucevişte & 10 & & & \\
\hline Karye-i Bigane & 2 & & 2 & & \\
\hline
\end{tabular}




\section{KAYNAKÇA}

370 Numaralı Muhasebe-i Vilayet-i Rum-İli Defteri (937/1530). Cilt I. T.C. Başbakanlık Devlet Arşivleri Genel Müdürlüğü Osmanlı Arşivi Daire Başkanlığı. Ankara 2001.

Abaz N. (2012). 15.-17. Yüzyllar Arasında Osmanlı Dönemi Üsküp Şehrinin Mimari Gelişimi. Yayımlanmamış Yüksek Lisans Tezi. Mimar Sinan Üniversitesi, İstanbul 2012.

Başar F. (1997). Osmanlı Eyâlet Tevcihâtı (1717-1730). Ankara 1997.

Başbakanlık Osmanlı Arşivi (BOA), NFS.d.5624 Numaralı Nüfus Defteri.

Çağ G. (2004). 217 Nolu Tapu-Tahrir Defterine Göre Paşa Sancă̆ı. Yayımlanmamış Yüksek Lisans Tezi. Sakarya Üniversitesi, Sakarya 2004.

Çokuğraş I. (2013). "Osmanlı İstanbul'unda Bekâr Odaları". Mimar.ist 47 (2013) 29-35.

Dede M. (2015). Üsküp Vakıfları -Bir Sosyal Tarih Íncelemesi-. Yayımlanmamış Doktora Tezi. Gazi Üniversitesi, Ankara 2015.

Evliya Çelebi. (2013). Günümüz Türkçesiyle Evliya Çelebi Seyahatnamesi: 1-6. Kitaplar. Cilt 1. Haz. S. A. Kahraman \& Y. Dağlı. İstanbul 2013.

Hoca N. (1984). "Üsküb”. MEB İslam Ansiklopedisi (Cilt 13) 122-127. Ankara 1984.

İnbaşı M. (1995). Osmanlı İdaresinde Üsküp Kazâsı (1455-1569). Yayımlanmamış Doktora Tezi. Atatürk Üniversitesi, Erzurum 1995.

İnciciyan P. L. \& Andreasyan H. D. (1973-74). “Osmanlı Rumelisi Tarih ve Coğrafyası”. Güneydoğu Avrupa Araştırmaları Dergisi 2-3 (1973-1974) 11-88.

Kul E. (2013). XVII. Yüzyılda Üsküb Şehri. Yayımlanmamış Doktora Tezi. Atatürk Üniversitesi, Erzurum 2013.

Stojkov R. (1970). "La Division Administrative de L'Eyalet de Roumélie Pendant les Années Soixante du XVII. Siècle Selon un registre Turc-Ottoman de 1668-1669". Studia Balcanica 1 (1970) 205-227.

Stoyanovski A. (1974). "XVII. Yüzyılın Sonuna Kadar Makedonya'nın Osmanlı Hâkimiyeti Devrinde İdarî Taksimatı". I. Ü.E.F. Tarih Enstitüsü Dergisi 4-5 (1974) 213-230.

Turan Ş. (1963). "XVII. Yüzyılda Osmanlı İmparatorluğu'nun İdarî Taksimatı (H.1041/M.01630-32 Tarihli Bir İdarî Taksimat Defteri)". Atatürk Üniversitesi 1961 Ylllığı (1963) 201-232. Ankara. 